\title{
GEOGRAFIA E LITERATURA: \\ UMA LEITURA DA CIDADE NA OBRA POÉTICA DE PAULO LEMINSKI
}

\author{
Júlio César Suzuki ${ }^{1}$ \\ Professor da Universidade de São Paulo \\ jcsuzuki@usp.br
}

Resumo

As mediações estabelecidas entre os poetas e a cidade foram pouco discutidas pela Geografia. Assim, pretendese, com esse trabalho, analisar a cidade que se constrói na obra poética de Paulo Leminski, tendo como referência sua trajetória intelectual, sobretudo as influências presentes na construção de sua poética, mas, também, as mediações construídas em relação às cidades em que viveu, particularmente a de Curitiba.

Palavras-chave: Geografia, Literatura, cidade, poeta, mediação.

\begin{abstract}
Résumé
Les médiations etablies entre les poètes et la ville ont été peu discutées par la Géographie. Ainsi, on veut, avec ce texte, analyser la ville qui est construit dans l'oeuvre poétique de Paulo Leminski, en valorisant sa trajectoire intellectuelle, surtout les influences presentes dans la construction de sa poetique, mais, aussi, les médiations construites en rapport les villes où il a habité, particulièrement la ville de Curitiba.
\end{abstract}

Mots-clef : Géographie, Littérature, ville, poète, mediation.

\section{L'ÊTRE AVANT LA LETTRE}

\author{
la vie en close \\ c'est une autre chose \\ c'est lui \\ c'est moi \\ c'est ça \\ c'est la vie des choses \\ qui n'ont pas
}

un autre choix

(LEMINSKI, 2002b:5)

Paulo Leminski² , já no final da década de 1980, era um nome conhecido. Mesmo nos rincões do Brasil, seu nome era ouvido, sobretudo por aqueles jovens instigados pela Filosofia, pela Música e pela Literatura.

Em Rondonópolis, no interior do estado de Mato Grosso, antes mesmo de nossa entrada, como aluno, no curso de Graduação em Geografia, no ano de 1989, tínhamos tido notícias de um jovem poeta: Paulo Leminski.

Uma década e meia após esse nosso primeiro contato, novo encontro se estabelece no final do curso de graduação em Letras na Universidade Federal do Paraná. Agora, como uma voz poética que traduz uma leitura da cidade; não só aquela em que nasceu e viveu - Curitiba ${ }^{3}$-, mas, também, em outras em 
que trabalhou - São Paulo e Rio de Janeiro -, além daquela, bem como outras onde esteve algum tempo em eventos acadêmicos - como Belo Horizonte e Londrina - ou as quais visitou pela ficção - Petrogrado...

É sobre a leitura da cidade empreendida por Paulo Leminski que se constitui este texto. Pretendemos analisar a cidade que se delineia em sua obra poética, tendo como referência sua trajetória intelectual, sobretudo as influências presentes na construção de sua poética, mas, também, as mediações construídas em relação às cidades em que viveu, particularmente a de Curitiba.

$\mathrm{Na}$ análise dos poemas, teremos como essencial os ensinamentos de Antonio Candido em $O$ estudo analítico do poema, mas com a liberdade de transitar, sobretudo, para a interpretação, sem muitas referências ao outro momento importante da análise do poema: o comentário. A análise será estruturada em três momentos: a) A construção da poética de Paulo Leminski, no qual se pretende discutir as influências estéticas de Paulo Leminski e a construção da sua poética; b) O poeta na cidade, cujo objetivo é o de delinear um pouco da relação que o poeta estabeleceu, sobretudo, com a cidade de Curitiba, o locus principal de sua vivência social; e c) A cidade no poeta, em que pretendemos apresentar e analisar os poemas em que aparece diretamente a cidade ou a expressão de seu movimento.

\section{A construção da poética de Paulo Leminski}

\section{DIVERSONAGENS SUSPERSAS}

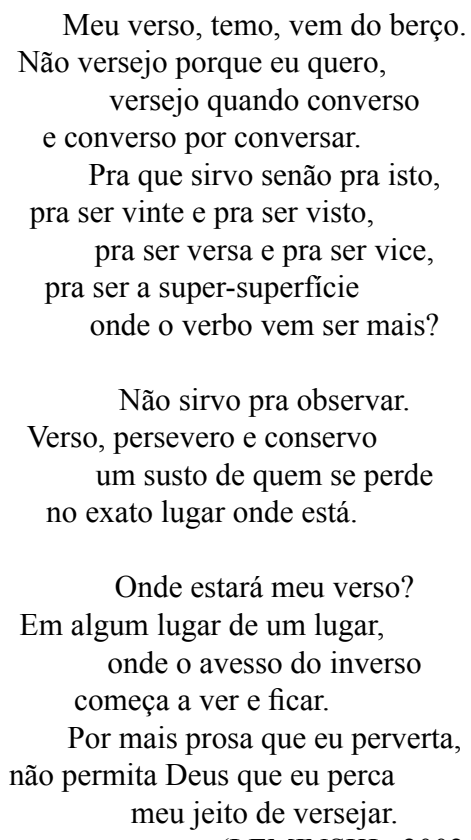

(LEMINSKI, 2002a:83)

No espaço da cidade, Paulo Leminski passou muitos dos seus 44 anos e ali viveu muitas experiências e estabeleceu várias mediações. São algumas dessas experiências e mediações que aparecem em seus poemas, numa voz lírica despojada, mas rigorosa; de samurai e malandro, segundo expressão cunhada por 
Leyla Perrone-Moisés (1994:55-6) e traduzida por Fred Góes e Álvaro Marins (1996:23): “(...) samurai (a imagem da máxima disciplina) e malandro (o antidisciplinado típico)”, num “(...) hibridismo entre o capricho sem sisudez e o relaxo atento (...)". Contradição aparente permeada por várias outras, conforme identificou, na biografia de Leminski, Toninho Vaz:

Para compensar alguma possível tendência para o relaxo, cortejado quase sempre nas esferas dedicadas a Eros, o deus da sensualidade, havia os momentos de extremo rigor, que continuavam permeando de informação e conhecimento os dias de Leminski no mosteiro (...). (VAZ, 2001:43) ${ }^{4}$

(...) equilíbrio tênue entre o relaxo e o rigor (...). (VAZ, 2001:83)

(...) Acentuavam-se-lhes, nesta época [meados da década de 1970], as contradições: era erudito e popular, arrogante e humilde, carinhoso e mordaz, trabalhador e preguiçoso, preto e branco (...). (VAZ, 2001:182).

Estas são contradições aparentes, já que o seu trabalho não era o do cotidiano regular do horário comercial das empresas, do homem preocupado com as atividades triviais (como tomar banho, escovar os dentes, ler contratos, tirar documento de identidade...), mas a do poeta que vive intensamente a poesia, conforme a fala de vários de seus contemporâneos, como ilustra bem a de Ademir Assunção: "Paulo Leminski é o poeta mais intenso que já conheci. Jamais encontrei outro que 'respirasse' poesia todo o tempo (...)" (VAZ, 2001:338). Ou em sua própria fala, em entrevista à Biblioteca Pública do Paraná:

(...) Eu não sou poeta de fim de semana, nem faço por hobby, como quem faz poesia quando vai para a praia. Faço poesia 24 horas por dia. Montei a minha vida de tal forma que a produção textual, seja ela qual for, é que me permite pagar o aluguel no fim do mês, a escola das minhas filhas, o meu cigarro, o vinho. Para mim, não há hora, de preferência as 24 horas do dia, isto é, a qualquer hora. Inclusive, existem versos que me vieram em sonho. Quando acordei de manhã disse: 'Puxa, me veio uma frase.' Isso me acontece, não com freqüência, mas acontece (...). (LEMINSKI, 1985:13).

A dificuldade de seguir o horário comercial das empresas fica bastante clara na sua fala sobre o abandono da atividade docente:

- Eu sou um professor frustrado. Acho que sou um professor na medida em que consigo transmitir clareza, porque procuro clareza para mim, para as coisas que me interessam. Mas acontece que na mecânica de transmissão do saber há um ponto incompatível com o meu lado contracultural, meio hippie, meio bandido. Acordar às 8 horas, em plena segunda-feira, para dar aula é incompatível comigo. Peguei toda uma banditice meio boêmia, que é um dado fundamental meu. Sou um bandido que sabe latim. (apud VAZ, 2001:151).

Esse lado meio hippie, meio bandido, identificado como contracultural é o que relaciona Paulo Leminski com toda uma geração de poetas, alguns identificados como "poetas marginais". Segundo Heloisa Buarque de Hollanda (1992:96), “(...) as manifestações marginais aparecem como uma alternativa, ainda que um tanto restrita, à cultura oficial e à produção engajada vendida pelas grandes empresas”.

Desses poetas, as marcas mais densas eram, sobretudo, uma poética do cotidiano de expressão do eu e a busca por uma estratégia de edição independente.

Flora Sussekind (1985:67) chega a afirmar que “(...) São as vivências cotidianas do poeta, os fatos mais corriqueiros que constituirão a matéria da poesia (...)”, citando um dos poemas de Leminski presente em Polonaises: "moinho de versos/ movido a vento/ em noites de boemia/ vai vir o dia/ quando tudo que eu diga/ seja poesia". Mas não o cotidiano como reminiscência; apenas como acaso e registro imediato (SUSSEKIND, 1985:67-8).

Em relação ao registro imediato, há mesmo até uma certa valorização no ato de poetar que se eviden- 
cia numa poesia do acaso e da falta de esforço, como se percebe no poema "POESIA: 1970", de Paulo Leminski:

POESIA: 1970

Tudo o que eu faço alguém em mim que eu desprezo sempre acha o máximo.

Mal rabisco,

não dá mais pra mudar nada.

Já é um clássico.

(LEMINSKI, 2002a:97).

Mas não há obra em que o registro imediato esteja mais evidente do que em Winterverno, já que os poemas e os desenhos foram feitos, por Paulo Leminski e João Suplicy, respectivamente, regados a cerveja, em mesa de bar, sem a preocupação de fazer poesia, mas a de realizar alguma atividade enquanto se conversava. É o que está muito bem expresso no depoimento de João Suplicy:

Em princípio, as coisas apareciam como se Paulo e eu jogássemos conversa para fora e para dentro. De cada tema surgia uma simbologia expressa por nós, como se fosse uma resposta ao outro (à maneira dos cantadores repentistas, ou dois ocidentais orientando-se em com/fabula/coes, tankas).

Cada trabalho possui uma história, um fato gerador, um insight colhido do ar, da inspiração pelo que se via e se vivia. Estávamos no final da década de 80. A sensação era a de que podíamos nos distrair, contanto que vivêssemos o aqui e agora, temperos necessários para que o vento passasse por dentro. (SUPLICY, 2001:s.p.)

Poesia do acaso, também, muito bem identificada pelo depoimento de Josely Vianna Baptista, a pessoa que teve o cuidado de ir recolhendo as anotações feitas, dia-a-dia, mesmo sem o conhecimento dos dois artistas (Paulo Leminski e João Suplicy):

Vieram versos, vieram desenhos, e veio o inverno. Um dia, já com um feixe desses instantâneos na mão, mostrei a eles o fruto do furto. Paulo se animou e, de conluio com João, resolveu desfazer esse efeito do deus Acaso. No mesmo Café Poesia, noite já fria, enevoada, fez-se o título, óbvio port-manteau de 'winter' e 'inverno', que se irradiava em leque de iridescências semânticas posto a nu num papel pardo. (BAPTISTA, 2001:s.p.).

A presença do registro imediato do cotidiano, na poesia marginal, também, foi identificada por Heloisa Buarque de Hollanda:

(...) a marca da experiência imediata de vida dos poetas, em registros às vezes ambíguos e irônicos e revelando quase sempre um sentido crítico independente de comprometimentos programáticos (...). (HOLLANDA, 1992:98).

O sentido crítico independente é tão marcante que poderíamos até questionar a existência de um grupo. É o que nos permite a ponderação de Heloisa Buarque de Hollanda:

(...) Se algum programa for exigido, ele deve ser buscado na própria ausência de programa do grupo, vista como recusa a perspectivas finalistas que incorporem a dinâmica da história e, conseqüentemente, a utopia. Esse é exatamente um dos traços que configuram seu projeto e de onde tiram sua maior força subversiva. (HOLLANDA, 1992:102). 
A falta de um projeto, ainda, se intensificava na ausência de uma articulação entre os poetas na divulgação da obra, já que havia uma busca pela edição independente de cada trabalho, o que era uma outra maneira do "eu" se colocar (SUSSEKIND, 1985:70).

Sobre a produção independente das obras dos poetas identificados como marginais, Heloisa Buarque de Hollanda afirma que:

Começam, então, a proliferar os livrinhos que são passados de mão em mão, vendidos em portas de cinemas, museus e teatros. Mais do que os valores poéticos em voga, eles trazem a novidade de uma subversão dos padrões tradicionais da produção, edição e distribuição da literatura. Os autores vão às gráficas, acompanham a impressão dos livros e vendem pessoalmente o produto aos leitores (...). (HOLLANDA, 1992:97).

Essa lógica da produção independente foi muito marcante no início da carreira de Paulo Leminski, sobretudo com Catatau, Polonaises e Não fosse isso e era menos; não fosse tanto e era quase, antes da sua relação com a Editora Brasiliense, por meio da qual ocorreu a sua profissionalização.

Sobre a mudança da produção independente para a profissionalização dos poetas, Flora Sussekind é extremamente crítica:

(...) Os escritores (...), submetidos gradualmente a um processo de profissionalização inédito em termos de vida literária brasileira, começam, em maior número, a 'viver de literatura' (...). E a conviver com a idéia de que o livro, mais do que objeto cultural, na presente ótica mercantil, é uma mercadoria vendável e lucrativa (...).

(...) Trata-se, pois, com as mãos entrelaçadas às normas do consumo, de desqualificar o experimental, o que não pode ser veiculado para 150 mil leitores ou para milhões de telespectadores (...). E de olhar com desconfiança aquilo que não conta com a benção dos índices de vendagem da indústria do livro ou com as aspas eletrônicas dos media.

(...) na definição de um perfil intelectual para o escritor brasileiro dos anos 80 fica difícil ignorar sua posição frente ao mercado e suas exigências e à crescente industrialização de nosso sistema editorial. E se nos anos 70 a censura e a cooptação foram a trilha dupla a ser percorrida por uma produção cultural impelida a um diálogo constante com um Estado ora repressor, ora mecenas, a década de 80 introduz outro fiel nessa balança: a lógica do mercado. Com isso, abre-se outra trilha igualmente dupla. Não a da censura, mas a da profissionalização. Apontando de um lado para a possibilidade de dedicação exclusiva ao trabalho literário e de outro para o servilismo diante das leis de venda, para um mergulho arriscado no banal. (SUSSEKIND, 1985:88-90)

A crítica é, ainda, mais feroz em relação ao próprio Paulo Leminski, um dos mencionados como profissional da literatura: “(...) vide os exemplos de Leminski, poeta-tradutor contratado da Editora Brasiliense, ou de Flávio Moreira da Costa, com 'salário de romancista' na Editora Record (...)” (SUSSEKIND, 1985:89). Além de tomado como marco em sua crítica final em relação à profissionalização dos escritores nos idos de 1980:

Não é de estranhar, então, que Paulo Leminski (...) tome por oponente uma figura meio alegórica de 'crítico'. É assim mesmo que, nas suas novas funções de cronista de jornal, se refere à crítica como 'inútil' e 'incapaz de deflagrar um grande movimento artístico sequer' (...). Inimigo 'inútil', mas assassino: 'É o agente funerário da arte'. E ainda mais temível à medida que olha com desconfiança para a necessidade de diluição do próprio projeto estético e para a autopromoção como molas mestras da criação literária nesses tempos marcados pela lógica do consumo. E talvez seja mesmo essa uma das principais funções da crítica nos próximos anos: atuar como uma 'não-semelhante', capaz de olhar com desconfiança para as banalizações impostas pelas leis do mercado à produção literária e a um intelectual constantemente impelido a se converter ele mesmo em mercadoria vendável ou em simples garoto-propaganda. Diálogo entre literatura e crítica que pode se mostrar 
produtivo nessa década de 80 . E que já apresenta alguns resultados significativos como o aparecimento de uma literatura mais reflexiva em substituição à paixão expressiva de 70 e capaz de optar ora pelas trilhas do delírio, ora pelas vias imprevisíveis da elipse, ora por um discreto enlace com o ensaísmo. (SUSSEKIND, 1985:91)

A análise de Flora Sussekind, por mais que reconheça liames que integrem esses vários poetas das décadas de 1970 e 1980, alguns reconhecidos como "poetas marginais", não desconsidera suas diferenças; mesmo quando salienta que uma de suas características mais marcantes fosse a da valorização do “eu” (SUSSEKIND, 1985:69).

Por mais que a poética de Paulo Leminski tenha sofrido influência da poesia marginal, em um de seus poemas, a voz lírica ironiza o termo marginal para identificação de um tipo de poeta:

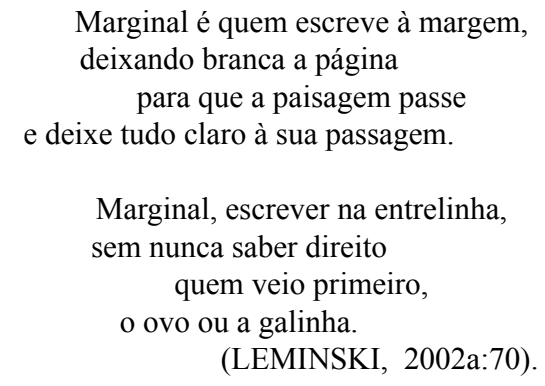

A poesia marginal, como uma perspectiva contracultural da década de 1970, foi uma de suas influências, como a da poesia concreta já estabelecida, na Semana Nacional de Poesia de Vanguarda, em Belo Horizonte, em 1963, com Haroldo de Campos, Augusto de Campos e Décio Pignatari; uma das matrizes de grande força na construção de sua poética. Não só da produção reunida, em 1976, em Quarenta clics em Curitiba; ou, em 1980, em Polonaises e Não fosse isso e era menos; não fosse tanto e era quase, mas, também, em Caprichos e relaxos, de 1983, que reúne os poemas dos dois livros anteriores e outros publicados em outros meios, bem como alguns inéditos. A mesma tendência encontraremos em Distraídos venceremos, de 1987; La vie en close, de 1991 (póstumo); O ex-estranho, de 1996 (póstumo); e Winterverno, de 2001 (póstumo).

A influência concreta, presente em toda a sua obra, não se tornou uma camisa de força, como nenhuma outra matriz poética, tal qual reconheceram, tendo em referência Caprichos e relaxos, Fred Góes e Álvaro Marins (1996:21):

(...) O livro (...) apresentava ao grande público um autor que tinha a capacidade de absorver criticamente, e sem sectarismos, todas as tendências poéticas de seu tempo e apresentá-las convertidas (ou até mesmo pervertidas) pela voz de sua individualidade.

Dos ditames mais fortes da influência concreta, Leminski se libertou logo após a publicação de Catatau em 1975. É o que identificou Sandra Novaes:

Nesse momento [1978], findada a fase de influência e mais livre para opinar, fica evidenciada a grande aprendizagem de Leminski com os concretistas e seu trabalho de poetas: a materialidade da linguagem, a possibilidade de manipulação da palavra, sua mobilidade como possibilidade de criação (...). (NOVAES, 2003:133)

Essa maior liberdade repercutiu em uma obra em que a influência concreta aparece, bem como a tendência contracultural da década de 1970, mas não para defini-lo lá ou cá. É bem o que, tomando como 
referência Rodrigo Garcia Lopes, afirmou Sandra Novaes (2003:169):

Segundo Rodrigo Garcia Lopes, poeta e leminskiano convicto, 'não se deve rotular a poesia de Leminski de 'alternativa', 'anos 70', ou 'marginal'. Leminski estava 'à margem da margem', elaborando, silenciosamente sua obra no bunker da Cruz do Pilarzinho, sem cortar seu diálogo com o mundo. Além disso, conseguiu o mais difícil em matéria de poesia: diç̧ão, que é a maneira pessoal e intransferível de um poeta poetar' (...).

Sandra Novaes (2003:169), corroborando a interpretação de Rodrigo Garcia Lopes, cita Rômulo Salvino:

(...) O próprio autor do Catatau já foi muitas vezes arrolado como participante do grupo marginal, mas certamente não é correta essa inclusão; com sua trajetória extremamente pessoal, ele deve ser visto mais como uma espécie de índice de todos os trajetos e indefinições do período: surgiu num veículo de matriz concretista (Invenção), praticou uma poesia de evidente índole visual, flertou com a Marginalia, contribuiu com revistas de várias tendências, assumiu um papel ativo na música popular com nomes como Caetano Veloso e Morais Moreira.

A existência de uma dicção própria na poética de Paulo Leminski em relação às várias matrizes poéticas que o influenciaram, também, foi muito bem identificada por Maria Esther Maciel:

(...) Embora tenha transitado por várias tendências poéticas em evidência no seu tempo e dialogado com distintas tradições, ele nunca se deixou confinar em gerações ou grupos específicos. Para ele, a relação com seus pares e precursores passava também pela 'desleitura'. Incorporou o legado oswaldiano e a tradição japonesa dos haikais e dos samurais, formou-se na poesia marginal da década de 70, manteve um contato criativo com a poesia concreta e com o tropicalismo, mas ousou afirmar sua própria dicção, inventar um caminho só seu, feito sobretudo de desvios em relação às vias já fixadas. (MACIEL, 2003:11).

Essa relação de "desleitura" com as tradições que o influenciaram ficou muito marcada na palestra que proferiu sobre poesia a convite de Adauto Novaes para Fundação Nacional de Arte (FUNARTE), em 1986, cujo título foi “Poesia: a paixão da linguagem”. Em relação à poesia marginal, vê-se como formado em seu bojo, mas dela se distancia, sobretudo ao valorizar o rigor formal, cujo maior representante seria João Cabral de Melo Neto:

(...) A gente está preso, preso mesmo, preso à forma, como preso à língua portuguesa. Minha formação poética vem dos anos 60 pros 70 . Vi, por exemplo, aparecer nos anos 70, em particular, uma tendência poética brasileira generalizada que ainda não acabou, a chamada poesia marginal, alternativa, uma poesia, como é que eu vou dizer, de manga da camisa, poesia feita assim sem nenhuma aparência de rigor formal. Mas isso sozinho não resolve. Hoje eu sinto, por exemplo, que se desenvolve uma tendência no sentido da recuperação de um certo rigor formal pra caracterizar o próprio fazer poético, que tem meio como padrinho o João Cabral de Melo Neto, que acho que qualquer um concordaria é o maior poeta brasileiro vivo, escrito, no papel, porque cantado, pra mim, é Caetano Veloso. João Cabral de Melo Neto seria uma espécie de patrono dessa recuperação de um rigor poético e a própria música popular, porque a música marca o lance da métrica, e o lance da rima como alguma necessidade (...). (LEMINSKI, 1995:296).

Em relação à poesia concreta, a sua fala remete às incorporações que realizou, sobretudo no que concerne às possibilidades que se constituíram quanto à palavra se abrindo para outros códigos que não somente o verbal:

(...) no caso dos poetas concretos, que trouxeram a tônica pro lance plástico, visual, a poesia como poster. A poesia como canção, a poesia como poster, ela não é mais palavra porque é a palavra atritando com uma outra coisa, é a palavra cruzando o outro código. A poesia seria o lugar onde a palavra cruzada com outros 
códigos se abre para outros códigos, por isso os poetas são interessados por cinema, fotografia, desenho (...).

(LEMINSKI, 1995:302).

Quanto aos haicais, a liberdade fica muito mais evidente que em relação às outras tradições, pois, sobre estas, o que se evidencia é a despreocupação em ser um poeta rigorosamente de uma delas. No entanto, em relação aos haicais, Leminski chega a mencionar a possibilidade de romper com a forma construída há gerações, sobretudo porque é uma construção social que pode ser reinventada:

(...) Então, se nascemos em determinado momento histórico em que há determinadas formas inventadas, não quer dizer que essas formas não possam ser quebradas ou, nem sei se o termo é bom, superadas, pelo menos, que apareçam outras formas... É a vida que inventa novas formas (...). (LEMINSKI, 1995:304)

Tal qual o haicai, toda a linguagem poética é uma construção social da qual se utiliza o poeta. Até mesmo para o seu reconhecimento, como afirmou o próprio autor em entrevista à Biblioteca Pública do Paraná:

(...) A linguagem poética, como todas as linguagens, é uma linguagem social. Nós temos que trabalhar com clichês, temos que trabalhar em cima dos lugares-comuns, criar coisas boas sobre fórmulas manjadíssimas. $\mathrm{O}$ projeto de uma originalidade absoluta é uma utopia. Ela existe enquanto horizonte para criar o absolutamente novo, aquilo que não deva nada a ninguém. Mas a gente sabe que na prática histórica isso não se verifica. Porque são formas sociais, e se nós não as adotamos, não somos reconhecidos. (LEMINSKI, 1985:32).

É nessa poética, marcada por influências estéticas de matrizes diversas - mas com extrema liberdade em relação a elas -, que vai ser construída uma representação da cidade, de fortes tintas de uma tradição humanista - alcançada em uma busca de incorporação pessoal, extremamente intensa, desde a mais tenra idade.

\section{0 poeta na cidade}

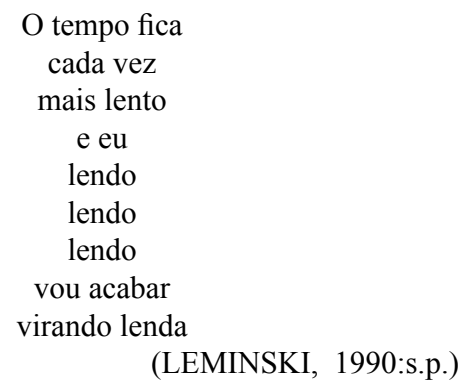

Paulo Leminski se tornou, realmente, lenda, em Curitiba, sua cidade natal. Nascido em 24 de agosto de 1944, no bairro da Água Verde (VAZ, 2001:19), filho de pai de origem polonesa e mãe mestiça de português, negro e índio; um mestiço curitibano, conforme sua própria descrição:

Paulo Leminski, signo de Virgem, 24 de agosto de 44. Nascido em Curitiba. Minha família, do lado de papai, é de origem polonesa e do de minha mãe, brasileira, com a composição original tipo Gilberto Freire. Português, negro e índio. De maneira que eu sou, digamos assim, um mestiço curitibano. Não tenho nenhum curso universitário completo. (LEMINSKI, 1994:9) 
Mesmo nunca tendo concluído um curso universitário, manteve-se muito antenado com o que estava acontecendo, em termos de cultura, em São Paulo e Rio de Janeiro, sobretudo. Tanto que Leyla PerroneMoisés chegou a afirmar que:

A Curitiba de Paulo Leminski, onde o poeta vive e é professor de judô, não é uma prisão, mas apenas o ponto de partida, o lugar de onde se olha o mundo para recriá-lo em versos. (PERRONE-MOISÉS, 1994:52).

Mas, mesmo não sendo uma prisão, Leminski sentia-se isolado, sem ter com quem discutir suas angústias, seus projetos, sua obra, além de Alice Ruiz ${ }^{7}$, com que esteve casado entre 1968 e 1987 (VAZ, 2001:93ss e 274ss). A ausência de diálogo fica bastante marcante, ao menos naquele final da década de 1970, em carta a Régis Bonvicino:

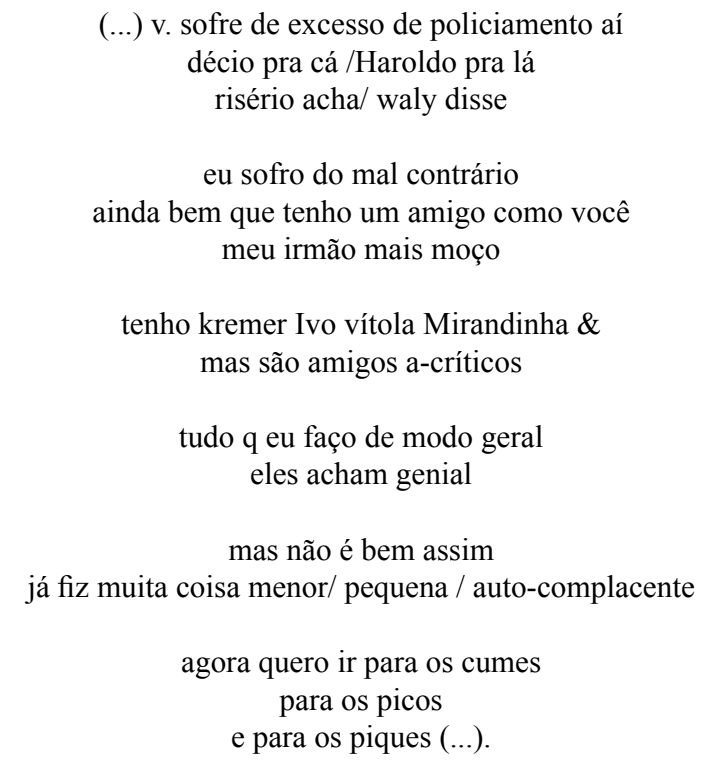

(LEMINSKI; BONVICINO, 1999:157-8).

Esse sentimento de isolamento aparece, ainda, em vários outros momentos de sua produção, mas não tão radical tal qual apareceu em sua carta a Bonvicino, anteriormente citada, como conseguiu capturar Sandra Novaes (2003:88):

(...) É bem provável que Leminski se sentisse só na provinciana Curitiba dos anos 70, essa província que era também uma província literária, mas talvez não ao ponto de não ter com quem dividir seus anseios intelectuais, além de Alice. Ele tenta explicar essa solidão. Na entrevista (...) com Rosimeri Gemael, 1986, diz o seguinte: '... se você olha os escritores do Paraná, tirando Dalton Trevisan que já é consagrado, da minha geração o primeiro a conseguir visibilidade no eixo Rio-São Paulo foi o Domingos Pellegrini, de Londrina, que uns oito anos antes de mim já tinha livro pela Civilização Brasileira. Depois a Alice conseguiu ser editada pela Brasiliense, o Roberto Gomes tem livros editados e paramos por aí. Não consigo lembrar de outros nomes...

Para além da Literatura, Leminski reconhece, em entrevista a Almir Feijó, de 1978, uma parca produção 
cultural, da qual sobressai Dalton Trevisan, mas que não desempenha, na cidade de Curitiba, o papel de intelectual, já que não participa da sua dinâmica de forma atuante para além de suas obras:

(...) Nós, em Curitiba, produzimos em termos de música popular o quê? Produzimos a figura isolada do Lápis, que não chegou propriamente a se realizar. É um valor, mas um valor que não chegou a sair do perímetro urbano. Não chegou a se afirmar como valor nacional. E nós temos músicos agora, da nossa geração atuando aqui em Curitiba. Tem atuações importantes, como a do Paulo Vítola, nesse terreno, mas também não chegou a hora da projeção do trabalho dele a nível nacional. Então, como no terreno da música popular, a gente teria espaço num outro terreno, o terreno plástico. Existe um setor em que Curitiba está bem servida, em termos de criação, que é o setor de cartun. Curitiba tem pelo menos umas cinco, seis figuras de nível nacional. Alguns nacionalmente e até um internacionalmente lançado. Tem o Mirandinha, que é internacional e de valor nacional. Solda, Retamozzo, Belenda. Que são figuras que não perdem nada para aqueles que estão batalhando lá no front do cartun no eixo Rio-São Paulo e a qualquer hora podem ir pra lá. No terreno das artes plásticas, também em Curitiba não tem um nome para afirmar nacional ou internacionalmente. No terreno da literatura só temos uma super-estrela, que é o Dalton Trevisan. Mas é uma figura, assim, absolutamente isolada, porque ele escreve mas ele não tem existência cultural. A presença dele não é uma atuação. Ele não atua. Não agita. Não organiza nem desorganiza. Não polemiza. Nada. (...) As pessoas não são obrigadas a fazer as mesmas coisas. Mas apenas constato que o sucesso da pessoa dele começa e se esgota na própria pessoa dele, porque ele não milita propriamente no front intelectual e cultural da cidade (...). (LEMINSKI, 1994:14-5).

Por conta dessa parca produção cultural em Curitiba, Sandra Novaes identifica que se constrói a imagem de poeta exilado:

Essa imagem do grande poeta morando na província e que busca diálogo com pessoas de fora da cidade, vai ser sustentada por ele [Paulo Leminski] e vai representar a garantia do sentimento de desconforto, do desencaixe, do 'not belonging', do eterno 'exílio' dentro da cidade, atitudes que vão qualificá-lo (...) como uma figura que se estrutura e se constrói pelo negativo, isto é, pelo avesso, que faz do não-ser, o ser (...). (NOVAES, 2003:88).

Paulo Leminski tentou abandonar esse exílio por três vezes e não conseguiu: a primeira, na adolescência, quando vai estudar, no Mosteiro de São Bento, em São Paulo (VAZ, 2001:31-46); a segunda, quando tenta novos caminhos, no Rio de Janeiro, entre julho de 1969 e fevereiro de 1971 (VAZ, 2001:10433); e a terceira, após se separar de Alice Ruiz, em São Paulo, entre março e novembro de 1988 (VAZ, 2001:278-90 e 341).

No entanto, essas pequenas incursões por outras cidades nunca foram suficientes para retirá-lo de Curitiba, tanto que Leminski chegou a afirmar que "Nunca sai de Curitiba. Pinheiro não se transplanta" (VAZ, 2001:294), o que foi traduzido por Solange Rebuzzi:

(...) Certa vez, declarou em uma entrevista: 'Pinheiro, não se transplanta', explicando o porquê de nunca ter partido definitivamente de Curitiba, e na confidência pública percebemos a resistência curitibana, que o mantinha em solidão e em estado de escrita (...). (REBUZZI, 2003:74).

É o sentido que, também, encontra Sandra Novaes em relação a sua trajetória pessoal: o de nunca ter deixado Curitiba.

Sentia-se intelectualmente limitado pela 'província' de Curitiba, mas nunca saiu dela e o mais longe que chegou em termos geográficos foi perto: Rio de Janeiro e São Paulo ${ }^{8}$. Dentro de um espírito anti-nacionalista, achava que o Brasil, em plena ditadura, era 'uma abstração jurídica' e que 'gostaria de pertencer a uma nação onde pudesse ser patriota'. Mesmo assim, aqui [em Curitiba] viveu, escreveu e morreu. (NOVAES, 2003:27). 
Com Curitiba, Paulo Leminski manteve uma relação bastante conturbada. Interpretava-a como provinciana, mas com ela não rompeu. Crítica e aproximação. É o que identifica Sandra Novaes (2003:84-5):

(...) ele [Paulo Leminski] trava com a cidade de Curitiba uma ambígua luta: amor e ódio, liberdade e limites, reconhecimento e rejeição, extensão do corpo e recolhimento do espírito, encaixe e desencaixe. É possível imaginá-lo muitas vezes como o trapeiro de Baudelaire, descrito por Benjamin: 'Trapeiro ou poeta - a escória diz respeito a ambos; solitários, ambos realizam seu negócio nas horas em que os burgueses se entregam ao sono; o próprio gesto é o mesmo em ambos (...) é o passo do poeta que erra pela cidade à cata de rimas; deve ser também o passo do trapeiro que, a todo instante, se detém no caminho para recolher o lixo em que tropeça (...).

É a relação de um intelectual que não está de todo integrado ao movimento da cidade, mas que já não se assusta com o movimento da modernidade, conforme salientou Sandra Novaes (2003:26).

Paulo Leminski é um poeta que não está preocupado com a dinâmica que produz a cidade, mas com o movimento que se pode capturar pelas vivências que realiza. É, exatamente, um pouco dessas vivências/ experiências que aparece em sua obra. Não é por acaso que Sandra Novaes (2003:82) vai fazer menção à intimidade na relação entre o poeta e a cidade:

A relação entre Leminski e a cidade de Curitiba é tema recorrente na obra. Essa atitude aproxima-o de outros autores que criam com algumas cidades, bairros e ruas uma tal intimidade que fazem com que estes elementos tornem-se parte integrante de suas vidas e de seus escritos (...).

Das vivências/experiências com a cidade, não só a de Curitiba, mas sobretudo com ela, Leminski cria um universo multifacetado em flashes rápidos e consistentes dessa relação ambígua de amor e ódio, liberdade e limites, reconhecimento e rejeição, extensão do corpo e recolhimento do espírito, encaixe e desencaixe.

\title{
A cidade no poeta
}

\author{
um bom poema \\ leva anos \\ cinco jogando bola, \\ mais cinco estudando sânscrito, \\ seis carregando pedra, \\ nove namorando a vizinha, \\ sete levando porrada, \\ quatro andando sozinho, \\ três mudando de cidade, \\ dez trocando de assunto, \\ uma eternidade, eu e você, \\ caminhando junto
}

(LEMINSKI, 2002b:9)

não discuto

com o destino

o que pintar

eu assino 
A cidade está presente em poucos poemas de Paulo Leminski, o que acaba por constituir um pequeno corpus, mas o suficiente para analisarmos a forma como a cidade se relaciona com a sua poética, cuja matriz principal é a de liberdade em relação às poesias concreta e marginal, das quais sofreu influência, bem como dos haicais japoneses e do tropicalismo.

Seus primeiros poemas, no circuito para além de Curitiba, são os publicados na Revista Invenção, ainda em 1963 (VAZ, 2001:70) - republicados em Caprichos e relaxos, de 1983. No entanto, não é entre eles que haverá a primeira referência à cidade.

Apenas, em Quarenta clics em Curitiba, de 1976, vão ser publicados os primeiros poemas em que a cidade aparece. Aliás, a cidade de Curitiba é a grande referência do trabalho. Os poemas acompanham fotografias da cidade retiradas pelo artista Jack Pires. Assim, os poemas são selecionados para dar conta de uma imagem, estabelecendo uma relação mediática. É por conta disso que vão falar ou das ruas, ou da cidade, ou das casas, ou das pessoas... de Curitiba.

Essa primeira coletânea de seus poemas tem uma relação intrínseca com a cidade. É o que podemos perceber, a seguir ${ }^{10}$, nos poemas de Quarenta clics em Curitiba ${ }^{11}$, em que a referência é, sobretudo, a cidade ou parte dela (a rua).

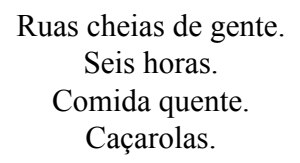

(LEMINSKI, 1990:s.p.)

Em "Ruas cheias de gente" 12 , encontramos um poema sem uma forma padrão. É um poema extremamente marcado por uma musicalidade que se constrói, a partir de rimas, entre os pares de versos mencionados, na sílaba final; além da repetição do som vocálico na penúltima sílaba (aliás, a última sílaba contada; tendo em vista que todos os versos têm paroxítonas como última palavra).

Assim, em termos de forma, o poema incorpora um pouco da tradição poética de musicalidade por rimas, mas dela se desprende no que se refere ao uso de uma forma padrão.

O poema, ainda, inova no que concerne à representação do movimento da cidade. Seu tema central.

O movimento não é garantido por verbos, mas pelo conjunto de substantivos: a) são "ruas" e "gente" que indicam o tráfego; b) "comida" sendo feita em "caçarolas; e c) numa certa "hora".

É um flash da cidade. Particularmente, uma fotografia ${ }^{13}$ do Centro, onde o movimento é maior. No entanto, a presença das "caçarolas" nos chama a atenção para a possibilidade do bairro, onde as famílias, às "seis horas", realizam o preparo do jantar. No poema, não é possível definir, efetivamente, o locus do movimento.

O movimento representado no poema "Ruas cheias de gente" é diferente do de "O olho da rua vê"; agora, construído a partir de dois verbos (ver e pensar), além do de ligação (ser). É um movimento de reconhecimento e distanciamento; em outros termos, identidade e alteridade.

O olho da rua vê

o que não vê o seu.

Você, vendo os outros, pensa que sou eu? 
O "olho da rua" pode ser interpretado como os que vivem a rua, o burburinho criativo dos boêmios, dos poetas; sobretudo, os que foram alijados do padrão genérico e normalizador ${ }^{14}$. Um olho que é um olhar: matizado com novas possibilidades de identificação, sobretudo porque expande os limites das unidades no conjunto. Quem sabe porque consegue, em si, delimitar mais as partes em que se compõe e, a partir delas, criar a identidade com as partes que identifica como semelhante a cada uma das suas. Uma vivência da cidade para além dos limites rígidos da alienação imposta pela reprodução do capital. Uma vivência do não repetitivo, do insurgente, do residual, do incomum.

Um olhar minucioso que não se identifica com o olhar dos que não vivem as sutilezas para além do dia-a-dia repetitivo do trabalho na cidade, pois é muito mais denso por conta de suas vivências; tal qual a música "Reconvexo" de Caetano Veloso:

\section{Reconvexo}

Eu sou a chuva que lança a areia do Saara Sobre os automóveis de Roma Eu sou a areia que dança

A destemida Iara, água e folha da Amazônia

Eu sou a sombra da voz da matriarca da Roma Negra Você não me pega

Você nem chega a me ver Meu som te cega, careta Quem é você?

Que não sentiu o suíngue de Henri Salvador

Que não seguiu o Olodum balançando o Pelô

E que não riu com a risada de Andy Warhol Que não, que não, e nem disse que não

Eu sou um preto norte-americano forte Com um brinco de ouro na orelha Eu sou a flor da primeira música

A mais velha e a mais nova espada e seu corte Eu sou o cheiro dos livros desesperados Sou Gita Gogoya

Seu olho me olha, mas não me pode alcançar Não tenho escolha, careta, vou descartar Quem não rezou a novena de Dona Canô Quem não seguiu o mendigo Joãozinho Beija-Flor

Quem não amou a elegância sutil de Bobô

Quem não é recôncavo e nem pode ser reconvexo

(VELOSO, 1989:s.p.)

Em "Reconvexo", o eu-lírico se distancia ainda mais do sujeito comum, de maneira mais radical, chegando até a uma certa arrogância, dispersa em todo o poema, mas sobretudo no verso em que questiona 
o Outro com um "Quem é você?". Mas é um pouco da distância que se estabelece, em "O olho da rua vê", quando o eu-lírico expressa "Você (...) pensa que sou eu?", marcando que não há como se comparar o sujeito comum consigo.

Os dois últimos versos, ainda, apontam para a ingenuidade desse sujeito comum que não consegue nada distinguir, chegando mesmo a achar que tudo é como ele, sobretudo porque suas práticas sociais não permitem ir além do reconhecimento do mundo a partir de si. Assim, tudo o que enxerga se matiza com as cores do seu olhar, com a sua normalização, ou seja, "você pensa que é você?"

A relação de alteridade, também, aparece no poema "Ainda vão me matar numa rua.", num movimento de identificação daquele que não segue o padrão; faz "(..) parte dessa gente/que pensa que a rua/é a parte principal da cidade."; reconhece as potencialidades de aprendizagem que rua permite e as utiliza, potencializando o seu significado em relação ao aconchego do lar, ou qualquer outro espaço fechado, protegido. A rua, então, é posta como a principal referência da cidade.

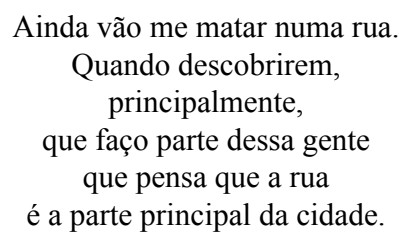

(LEMINSKI, 1990:s.p.)

No poema, chama atenção o terceiro verso que, construído apenas com um advérbio - é o único verso com uma só palavra - nuançando o verbo "descobrir", aponta para a possibilidade do assassinato ocorrer, também, por outras razões; desconhecidas para o leitor.

Nesse poema, ainda, uma relação se coloca entre os sujeitos comuns e os diferentes; todos na cidade numa relação de identidade e alteridade, sendo construída constantemente. Diferente do que ocorre no poema "Já não chove", em que já não há diferente entre uns e outros. Todos pisam o chão e tornam "As ruas pesadas". "Pesadas" pelos pés que a marcaram.

Imagem que já vinha sendo construída no verso anterior com mensagem muito similar, já que não são os pés que molham as pessoas no caminhar, mas são as pessoas que "molham" passos, ou seja, as pessoas vão deixando suas marcas numa rua em que já não chove, mas cuja água, que, provavelmente, ficou em pequenas poças, sirva para que as solas dos calçados marquem as suas passadas, deixando as ruas "pesadas" (pisadas) pelos pés.

$$
\begin{aligned}
& \text { Já não chove } \\
& \text { Pessoas molham passos } \\
& \text { As ruas pesadas } \\
& \text { (LEMINSKI, 1990:s.p.) }
\end{aligned}
$$

O sentido de coletividade, marcado por "pessoas" em sua perspectiva genérica, em "Já não chove", não se mantém no poema "O peito ensangüentado de verdades", cujo eu-lírico se expressa no uso da primeira pessoa do singular do verbo "rolar" no presente do indicativo, mostrando a contemporaneidade da ação. 
O poema guarda uma sintaxe intercruzada que só se resolve no terceiro verso. O primeiro verso mantém sua continuidade no terceiro, pois é um verso que só possui o sintagma nominal, não há verbos (a não ser que consideremos o particípio como verbo, mas, no verso em questão, seu uso é plenamente adjetival); o que conduz para a necessidade de sintagma verbal, cujo verbo esteja na terceira pessoa do singular; no caso o terceiro verso. No entanto, o segundo verso não se constitui numa oração intercalada, mas como uma oração independente sem relação com o sintagma nominal que constitui o primeiro verso. Mas, no segundo verso, há um referente ("esta cabeça calva e cega") para o pronome pessoal do caso oblíquo do terceiro verso que não pode ser encontrado no primeiro verso. Assim, há uma teia de relações que só se resolvem se pensarmos em vários pedaços, localizados em posições quaisquer, como que para chamar a atenção do leitor para uma situação incomum, rara: a de existir "O peito ensangüentado de verdades".

Coerente, em termos de sintaxe, seria pensar o segundo verso como primeiro. O primeiro como segundo e o terceiro onde está. Nesse caso, as relações entre os termos seriam plenamente satisfeitas.

A existência de um sujeito raro aparece, também, no poema “dois loucos no bairro", em Polonaises ${ }^{15}$, de 1980.

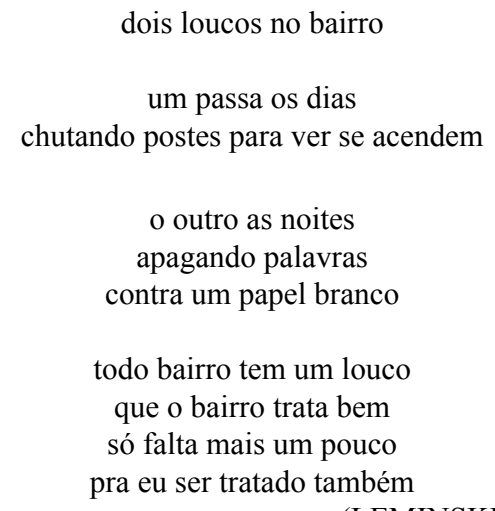

(LEMINSKI, 1980b:s.p.)

A estrutura do poema é bastante peculiar: apresenta um título (o que não é essencial em Leminski) que pode ser considerado o primeiro verso do poema, já que as estrofes vão se constituindo sempre com um verso a mais do que a anterior. Assim, a primeira seria o título, com apenas um verso. Mas, também, podemos considerar o título como o primeiro verso porque a idéia dos "dois loucos no bairro" vai ser ampliada nas estrofes seguintes, mas não reiterada como identificação sumária.

Tomando como referência o título como primeira estrofe, na segunda, é descrito um tipo de louco, o que chuta postes com o objetivo de verificar se acendem: "chutando postes para ver se acendem". Esse nos parece ser o tipo de louco visionário que procura encontrar o novo, como a lâmpada que, em alguns desenhos animados, representa uma nova idéia. O chute no poste parece-nos indicar o esforço da descoberta, da iluminação.

$\mathrm{Na}$ terceira estrofe, é um outro tipo de louco que se apresenta: o que apaga palavras no papel. A ima- 
gem poética que se constrói é extremamente contundente. A palavra, antes de sua fixação num contexto, possui muitos sentidos, é uma virtualidade em potencial. No entanto, ao impregnar o papel branco, a palavra é como se perdesse essa potencialidade de ser múltipla. Por mais que, ainda, haja mais do que um sentido possível, houve uma restrição das potencialidades, cujo artífice é o poeta; não só o da poesia, mas, também, o da prosa. São todos aqueles que apagam palavras contra um papel branco, mas que, também, se distanciam do sujeito comum, cuja escrita não é feita à noite, horário incomum na lógica que rege a reprodução da riqueza, entendida como capital: o horário comercial.

Esse tipo de louco, como aquele primeiro, se distancia, então, do sujeito comum, numa relação de alteridade. Mas não se gera a negação completa por parte do sujeito comum - a quase totalidade dos que estão no bairro -, quando este identifica um número restrito de sujeitos diferentes do padrão normalizado.

A situação é até de complacência: “(...) o bairro trata bem”. O que não significa plena aceitação ou integração. Mas pode significar um certo reconhecimento que, no caso do poema, ainda não foi alcançado pelo eu-lírico: "só falta mais um pouco/pra eu ser tratado também".

O poema "hoje o circo está na cidade" leva às últimas conseqüências à fuga ao padrão normalizado da lógica do trabalho como fundamento da reprodução da vida.

$$
\begin{aligned}
& \text { hoje o circo está na cidade } \\
& \text { todo mundo me telefonou } \\
& \text { hoje eu acho tudo uma preguiça } \\
& \text { esses dias de encher lingüiça } \\
& \text { entre um triunfo e um waterloo }
\end{aligned}
$$

(LEMINSKI, 1980b:s.p.)

No terceiro verso, o eu-lírico se expressa de forma contundente em relação à fuga à lógica do trabalho ("hoje eu acho tudo uma preguiça"); o que se evidencia no verso seguinte ("esses dias de encher lingüiça"). Estabelece-se, então, a lógica do vencer sem esforços, principalmente porque a conquista se realiza mesmo se achando tudo uma preguiça e se enchendo lingüiça, como se percebe no quinto verso: "entre um triunfo e um waterloo". A referência ao conflito, à possibilidade de enfrentamento e de esforço, na menção à Guerra de Waterloo, é quase que totalmente apagada com o uso de substantivo e expressão substantiva de negação do trabalho: "circo", "preguiça", "encher lingüiça".

Negação ao trabalho, também, presente no poema "desta vez não vai ter neve como em petrogrado aquele dia", tão presente nos verbos, em gerúndio, do terceiro verso de cada estrofe: "dormir e sonhar". Verbos que não carregam o sentido do esforço, mas o de sua negação: a) dormir como o não-trabalho; e b) sonhar como o que está para além do trabalho - a utopia.

O velho leon e Natália em coyoacán ${ }^{16}$

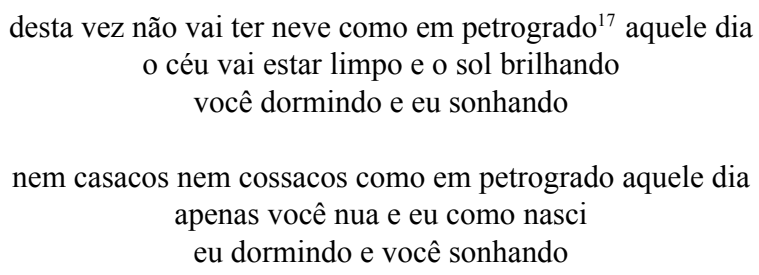


A negação do trabalho, na sua dimensão da utopia, ainda, pode ser capturado em outros termos: "a neve" (o que não é corriqueiro no Brasil); "aquele dia" (como um sonho ou uma recordação boa); "o céu vai estar limpo" e "o sol brilhando" (horizonte de possibilidades); "você nua" (nada a esconder); "eu como nasci" (tudo a ser feito, todas as potencialidades a serem escritas); "multidões gritando" (as pulsações se revelando); "silêncio nós" (palavras que não mais necessárias); "dois murmúrios azuis" (comunicação completa, sem ruídos, tal qual um céu azul sem nuvens); "nada como um dia indo atrás do outro vindo" (um caminhar sem empecilhos). Utopia que aparece com muitos matizes, até mesmo o do desejo que pode ser até carnal, o que se percebe na imagem construída por "você nua".

O desejo carnal é possível de ser lido no poema "escura a rua", como se, em um lugar de menor claridade, fosse possível, mesmo na rua, deixar aflorar o calor que queima o corpo, tornado "meu duro desejo" em ereção ("duro"). A imagem do desejo é, ainda, corroborada pelos termos "espuma" (lembrando esperma) e "explode" (lembrando orgasmo). Mas, estes dois termos fazem referência à força da água do mar que "espuma" e "explode" junto à praia, onde acabam as dunas. No entanto, as referências dos dois termos ao desejo carnal e à imagem da praia terminam por aí, pois em nenhum dos dois casos há dor entre "espuma" e "explode". Só para o poeta há uma espuma (como o fervilhar das idéias) que, construída com dor, irrompe como uma explosão.

$$
\begin{gathered}
\text { escura a rua } \\
\text { escuro } \\
\text { meu duro desejo } \\
\text { duro } \\
\text { feito dura } \\
\text { essa duna } \\
\text { donde } \\
\text { o poema } \\
\text { uma } \\
\text { esp } \\
\text { uma } \\
\text { doendo } \\
\text { ex } \\
\text { pl } \\
\text { ode }
\end{gathered}
$$

(LEMINSKI, 1980b:s.p.)

Em Não fosse isso e era menos; não fosse tanto e era quase ${ }^{18}$, a utopia aparece como sonho, mas não é tão tranqüilo. Há um certo sofrimento, uma certa dor, um certo medo, o que se evidencia em termos como "feras", "tiro", "fantasmas", "sombras", "coisas não feitas", "gritam", "demônios loucos". 


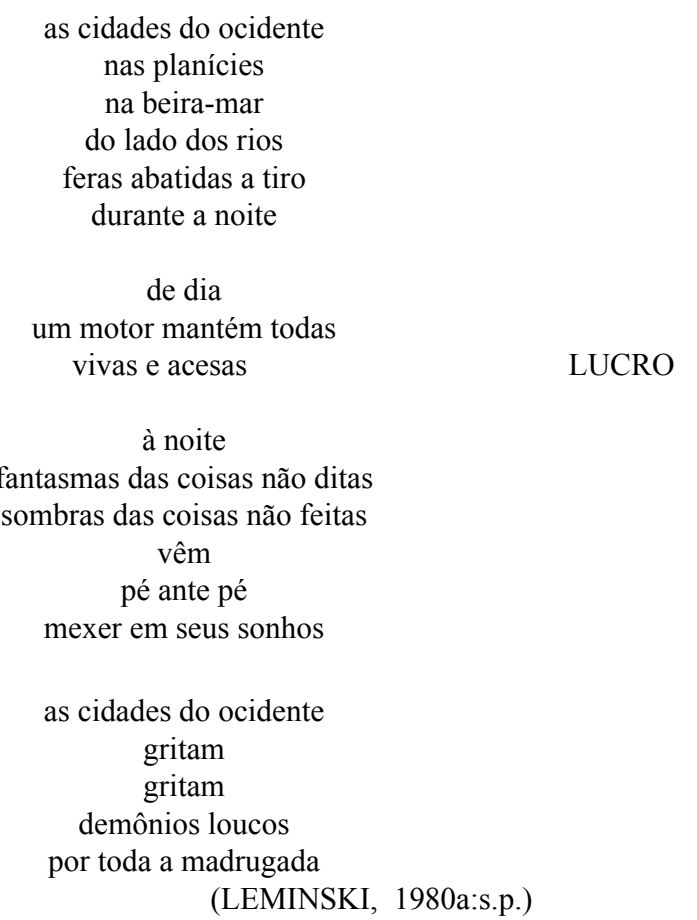

Todos os poemas, anteriormente analisados, publicados em Polonaises e Não fosse isso e era menos; não fosse tanto e era quase, integraram o livro Caprichos e relaxos ${ }^{19}$, de 1983. De Polonaises: "desta vez não vai ter neve como em petrogrado aquele dia" (LEMINSKI, 1988:45); "um passa os dias" (LEMINSKI, 1988:52); "escura a rua" (LEMINSKI, 1988:54); e "hoje o circo está na cidade" (LEMINSKI, 1988:55). E de Não fosse isso e era menos; não fosse tanto e era quase: "as cidades do ocidente" (LEMINSKI, 1988:91).

Em Distraídos venceremos ${ }^{20}$, o poema “Em Brasília, admirei.”, ao invés do sonho e da utopia, trará a possibilidade de superação de uma determinação da forma: a insurreição do uso no movimento de produção da cidade; o que se evidencia em "a vida das pessoas/penetrando nos esquemas", "(...) restaurante clandestino/criminoso por estar fora da quadra permitida" e "O erro, claro, não a lei.".

\author{
CLARO CALAR SOBRE \\ UMA CIDADE SEM RUÍNAS \\ (RUINOGRAMAS) \\ Em Brasília, admirei. \\ Não a niemeyer lei \\ a vida das pessoas \\ penetrando nos esquemas
}


como uma tinta sangue

no mata borrão,

crescendo o vermelho gente,

entre pedra e pedra,

pela terra a dentro.

Em Brasília, admirei.

O pequeno restaurante clandestino, criminoso por estar

fora da quadra permitida.

Sim, Brasília

Admirei o tempo

que já cobre de anos

tuas impecáveis matemáticas.

Adeus, Cidade.

$\mathrm{O}$ erro, claro, não a lei.

Muito me admirastes,

muito te admirei.

(LEMINSKI, 2002a:39)

A ação das pessoas se insurgindo num mundo matematicamente projetado, a cidade de Brasília, em que a história de cada uma e de todas foi reconstruindo a forma e o planejamento de uso de cada um dos pedaços que compõem o Plano Piloto da capital do Brasil. A cidade tendo seus referenciais construídos pela história das pessoas. Imagem muito diferente do que encontramos em "Nome mais nome igual a nome (...)", em que a cidade aparece muito mais como palco do que como produto da ação da sociedade; é o que se percebe na perda de significação que tem: "cidades passam. Só os nomes vão ficar". De cada uma, nenhuma marca, além do nome.

\section{NOMES A MENOS}

Nome mais nome igual a nome, uns nomes menos, uns nomes mais.

Menos é mais ou menos, nem todos os nomes são iguais.

Uma coisa é a coisa, par ou ímpar, outra coisa é o nome, par a par,

retrato da coisa quando límpida, coisa que as coisas deixam ao passar.

Nome de bicho, nome de mês, nome de estrela, nome dos meus amores, nomes animais, a soma de todos os nomes, nunca vai dar uma coisa, nunca mais.

Cidades passam. Só os nomes vão ficar. 
Por outro lado, "Cidades pequenas" marca a existência da densidade da história definindo os caminhos da própria constituição de Curitiba. Caminhos que constituem cidades diferentes; todas elas na mesma Curitiba; como se pode perceber no título e sub-título do poema. A definição de Curitiba é uma premissa sem muita precisão, pois paira uma dúvida do ar de qual efetivamente é a verdadeira Curitiba, ou além: se não há para cada um de seus moradores uma Curitiba única, sua. Não se pode, ainda, esquecer a Curitiba dos que já foram, num tempo de romarias, "cantilenas, ladainhas", cuja centralidade da dinâmica social estava na Vila de Nossa Senhora da Luz dos Pinhais.

Em Curitiba, ou no plural para abarcar cada uma das possibilidades e todas elas, delineia-se a vida do eu-lírico, como uma "definitiva preguiça", cujos caminhos assemelham-se à fumaça de um incenso, indecisa. A este sujeito lírico cabe, então, pedir a redenção às Curitibas, marcadas pelo seu ponto inicial de espraiamento: "Vila de Nossa Senhora/da Luz dos Pinhais,/tende piedade de nós".

\section{IMPRECISA PREMISSA}

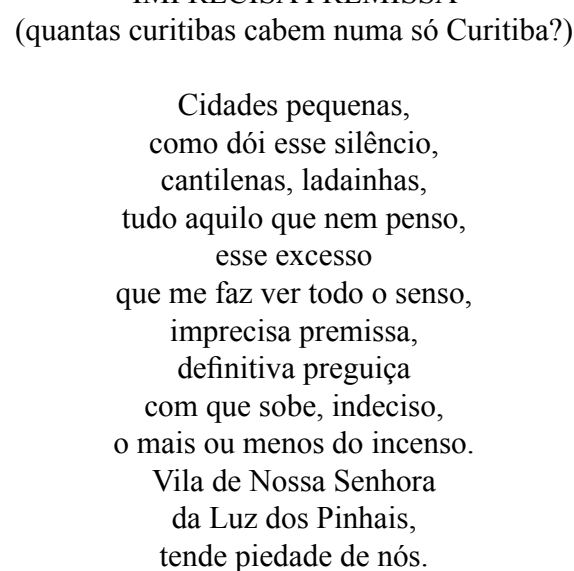

(LEMINSKI, 2002a:59)

Um pouco dessa imagem de cidade que nos significa, também, aparece em "você nunca vai saber": "o peso agudo no peito/de carregar uma cidade/pelo lado de dentro". No poema, a presença da memória fica muito bem definida na menção aos tempos verbais: "como passar do presente/para o pretérito perfeito"; mas cujo sentido é impreciso, já que o último verso da primeira estrofe aponta para um "nunca saber direito".

Além de um espaço relativo que se delineia na primeira estrofe, na segundo há, também, um tempo: "o que vem depois de sábado/quem sabe um século/(...) quem sabe apenas/mais um domingo".

$$
\text { OBJETO SUJEITO }
$$

você nunca vai saber 


$$
\begin{gathered}
\text { quanto custa uma saudade } \\
\text { o peso agudo no peito } \\
\text { de carregar uma cidade } \\
\text { pelo lado de dentro } \\
\text { como fazer de um verso } \\
\text { um objeto sujeito } \\
\text { como passar do presente } \\
\text { para o pretérito perfeito } \\
\text { nunca saber direito } \\
\text { você nunca vai saber } \\
\text { o que vem depois de sábado } \\
\text { quem sabe um século } \\
\text { muito mais lindo e mais sábio } \\
\text { quem sabe apenas } \\
\text { mais um domingo } \\
\text { você nunca vai saber } \\
\text { e isso é sabedoria } \\
\text { nada que valha a pena } \\
\text { a passagem pra pasárgada } \\
\text { xanadu ou sangrilá } \\
\text { quem sabe a chave } \\
\text { de um poema } \\
\text { e olha lá }
\end{gathered}
$$

(LEMINSKI, 2002a:96)

A última estrofe é bastante pessimista em relação às possibilidades de definição do que, efetivamente, pesa carregar, no peito, uma cidade: "você nunca vai saber"; como, também não, "a passagem pra pasárgada/xanadu ou sangrilá", mas, com muita sorte, pode ser que se consiga encontrar "(...) a chave/ de um poema". Porém, só com muita sorte mesmo, pois “e olha lá".

Em La vie en close $e^{21}$, também, aparece a relação que se constitui entre o eu-lírico e a cidade no poema "Conheço esta cidade". Na primeira estrofe, o eu-lírico expressa ter uma mapa mental da cidade - que, também, são várias, como sugere o título (“Curitibas”) -, resultante de uma experiência cotidiana, tal qual o conhecimento que se alcança dos caminhos do orgasmo no manejo do órgão sexual: "como a palma da minha pica"; por mais que tal órgão não possua palma como mão, o referente para o trocadilho que se usou de base para a formulação do verso: "conheço como a palma da minha mão".

A relação entre o eu-lírico e a cidade, marcada pelo prazer, expressa-se, além da menção ao órgão genital, nos termos "palácio" (como palácio dos prazeres) e "fonte" (como fonte de prazer), cujas localizações são de conhecimento de seu conhecimento: "sei onde a fonte fica (...)".

O resultado da saudade é desconhecido do eu-lírico. Mas, mesmo assim, ele se sabe "Ser": "Ser, eu sei (...)".

\section{CURITIBAS}

Conheço esta cidade

como a palma da minha pica. 
Sei onde o palácio

sei onde a fonte fica,

Só não sei da saudade

a fina flor que fabrica.

Ser, eu sei. Quem sabe,

esta cidade me significa.

(LEMINSKI, 2002b:16)

Alguma cidade pode ser muito bem conhecida, como se expressou o eu-lírico no poema anterior, no entanto, em outras, o seu enigma pode nunca ser desvendado. São fragmentos cujas histórias não se completam, como "os poemas incompletos", num movimento alucinante ("sirenes, bares em chamas,/ carros se chocando") que atrai ("a noite me chama (...)") e permite sempre um caminhar ("e o vermelho sempre verde dos sinais"), com certas restrições, como sugere "o vermelho" do último verso, por mais que sempre verde.

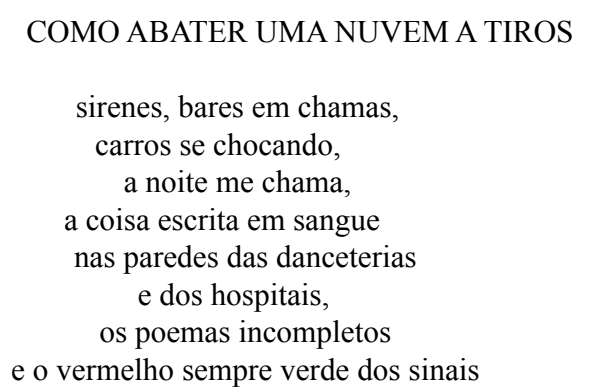

(LEMINSKI, 2002b:17)

A incompreensão de algumas cidades por parte do eu-lírico, bem como de seus significados, é muito bem expressa no poema "paulos paulos paulos", sobretudo em sua primeira estrofe, já que a segunda aponta para o dilema de não se estar só cá, mas, também, lá.

\section{COM QUANTOS PAULOS}

paulos paulos paulos quantos paulos são preciso para fazer um são paulo?

idades idades idades quanto dá uma alma dividida por duas cidades?

(LEMINSKI, 2002b:32)

A incompreensão da cidade que pode levar ao entorpecimento do eu-lírico que, de pedaço em pedaço da aglomeração, sem muito compreendê-la, atravessa-a, como num sono constante, como traduz o uso 
do gerúndio no verbo do último verso do poema "cinco bares, dez conhaques", traduzindo a permanência do processo.

$$
\begin{aligned}
& \text { cinco bares, dez conhaques } \\
& \text { atravesso são paulo } \\
& \text { dormindo dentro de um táxi }
\end{aligned}
$$

(LEMINSKI, 2002b:109)

Uma cidade inatingível que, ainda, aparece em "por mais que eu ande" de $O$ ex-estranho ${ }^{22}$, sobretudo no último verso: "numa cidade tão grande".

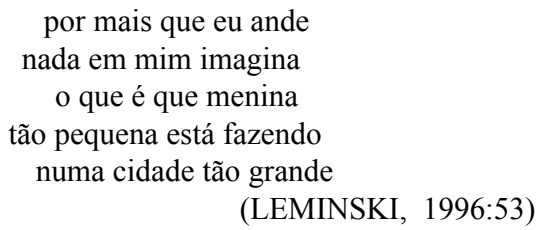

A cidade, na obra poética de Paulo Leminski, não se constitui apenas como uma imagem que permanece em todos os poemas, mas se delineia e se transforma, revelando muitas de suas faces, como múltiplos são os sujeitos que a vivem, mesmo os muitos que vivem em cada um de nós.

$$
\begin{aligned}
& \text { pronto } \\
& \text { aqui está } \\
& \text { o meu ponto }
\end{aligned}
$$

(LEMINSKI, 2001b:s.p.)

\section{Considerações finais}

$$
\begin{aligned}
& \text { o pauloleminski } \\
& \text { é um cachorro louco } \\
& \text { que deve ser morto } \\
& \text { a pau a pedra } \\
& \text { a fogo a pique } \\
& \text { senão é bem capaz } \\
& \text { o filho da puta } \\
& \text { de fazer chover } \\
& \text { em nosso piquenique }
\end{aligned}
$$

(LEMINSKI, 2001a:68)

Paulo Leminski foi, até entre os mais próximos, um incompreendido. Mesmo entre os que amam sua poesia, há muita dificuldade em digerir e entender o Catatau. Quem sabe porque a sua prosa tenha se 
constituído no mais poético de toda a sua obra. Aquele fragmento meio que intransponível em que "o olhar pára nas palavras" que não é próprio do romance, sendo só inteligível para outros que, como ele, nasceram com "uma espécie de erro na programação genética", os conscientes da linguagem:

A poesia, ela traz consigo esse caráter assim meio de, como é que eu vou dizer? Uma coisa meio masoquista. Você se dedicar dez anos a vender banana, montar uma banca para vender banana ou repolho, você vai ganhar muito mais do que fazendo poesia. A poesia não te dá nada em troca. Chego, às vezes, a suspeitar que os poetas, os verdadeiros poetas, são uma espécie de erro na programação genética. Aquele produto que saiu com falha, assim, entre dez mil sapatos um sapato saiu meio torto. É aquele sapato que tem consciência da linguagem, porque só o torto é que sabe o que é o direito. Então, o poeta seria, mais ou menos, um ser dotado de erro, e daí essa tradição de marginalidade, essa tradição, moderna, romântica, do século XIX pra cá, do poeta como marginal, do poeta como bandido, do poeta como banido, perseguido, enfim, em condições, digamos, socialmente adversas, negativas. Pensando nas relações entre poesia e linguagem, entre paixão, poesia e linguagem, formulei a coisa de que a poesia seria uma manifestação, sobretudo, de paixão pela linguagem, por causa do próprio caráter substantivo da poesia. Um poema não é como um conto, não é como um romance. Um conto, um romance são transparentes, deixam o olhar passar até o sentido. Na poesia, não. O olhar não passa, o olhar pára nas palavras (...). (LEMINSKI, 1995:284-5).

Diferente do que ocorre com os seus poemas (ao menos para o leitor de primeira viagem), cujos sentidos parecem estar tão claros.

A análise da representação da cidade, em sua obra poética, nos revelou que não há uma só cidade, mas são múltiplas; desenhadas em diversas faces fotografadas em instantâneos que traduzem muito de seu movimento.

Uma cidade marcada pela alteridade, pela diversidade, em que o seu tradutor é um eu-lírico experienciador da sua dinâmica. Mas não um sujeito comum. Um poeta marcado por uma lógica contra o trabalho alienante da tarefa repetitiva, realizada em horário comercial (mesmo que haja também outros turnos alienantes), o que evidencia as influências sofridas por Paulo Leminski da poesia marginal, mas, também, da poesia concreta e do tropicalismo que, cada tendência ao seu modo, mantiveram uma perspectiva contracultural.

A cidade, então, aparece pelo olhar de quem a viveu densamente, mas de modo fragmentado. Numa perspectiva de intervenção cultural, como um intelectual, mas de pouca monta no que concerne à dimensão política e social. Os poemas dão conta da escolha realizada; neles, aparece uma voz lírica que pouco discute o movimento de produção da cidade, mas a retrata no seu instantâneo volátil de metamorfose constante.

\author{
rio do mistério \\ que seria de mim \\ se me levassem a sério?
}

(LEMINSKI, 2002a:116)

\title{
Notas
}

(1) Graduado, em Geografia, pela Universidade Federal de Mato Grosso e, em Letras, pela Universidade Federal do Paraná, com Mestrado e Doutorado, em Geografia Humana, pela Faculdade de Filosofia, Letras e Ciências Humanas da Universidade de São Paulo.

(2) Seu pai se chamava Paulo Leminski. O escritor, Paulo Leminski Filho. No entanto, para manter a coerência com 
o seu nome popularizado, neste estudo, Paulo Leminski será sempre o filho.

(3) Ainda na infância, Paulo Leminski Filho reside em Itapetininga-SP (1949), Itaiópolis-SC (de 1949 a 1955) e Rio Negro-PR (1955 e 1956), por conta de transferências internas, no Exército, de seu pai Paulo Leminski, o velho (VAZ, 2001:26-29).

(4) Toninho Vaz nos fala do período em que Paulo Leminski permaneceu no mosteiro de São Bento, em São Paulo, de fevereiro de 1958 a janeiro de 1959 (VAZ, 2001:32 e 46).

(5) Aqui, Toninho Vaz está tendo como referência o período em que Leminski, casado com Neiva, mora no Edifício São Bernardo, após sua premiação no II Concurso Popular de Poesia Moderna de 1966, no qual alcançou o 1o lugar.

(6) Entrevista realizada, em 1978, por Almir Feijó, para a revista Quem.

(7) Alice Ruiz, quando conheceu Paulo Leminski, em 24 de agosto de 1968, já escrevia poesias, conforme relato de Toninho Vaz (2001:94): “"Alice falou de suas poesias e contou que estava morando no Rio de Janeiro (...)”. Durante seu casamento com nosso autor, manteve-se em processo de criação, tendo sido uma das escritoras publicadas, no início da década de 1980, pela Editora Brasiliense. Continua, ainda, em atividade poética, em parcerias com nomes importantes da Música e da Literatura nacionais.

(8) Vale lembrar que, além das cidades em que residiu na infância, Paulo Leminski, ainda participou da Semana Nacional de Poesia de Vanguarda, em Belo Horizonte, em 1963, ainda com 18 anos (VAZ, 2001:67-9), bem como de lançamento de vários de seus livros, em 1985 (conforme Jaime Lechinski, foi em 1988), juntamente com de Alice Ruiz, em Londrina (VAZ, 2001:254 e 336-7).

(9) Na primeira versão deste poema, publicado em Não fosse isso e era menos; não fosse tanto e era quase (1980:s.p.), o verso "eu assim" fora grafado com letra cursiva na horizontal. Na sua segunda versão, em Caprichos e relaxos (1988:75), aparece, ainda em letra cursiva, mas na diagonal ascendente; diferente do que ocorre em Melhores poemas de Paulo Leminski, cuja letra é de máquina, na horizontal, em itálico (indicando a diferenciação que se queria valorizar no verso).

(10) Os poemas de Quarenta clics em Curitiba não possuem uma ordem, tendo em vista que se constitui em uma coleção com 40 encartes, vistos na seqüência desejada. Assim, nossa apresentação segue uma ordem que vai dos poemas que se referem à cidade para os que tratam da relação do poeta com ela.

(11) LEMINSKI, Paulo. Quarenta clics em Curitiba. 2.ed. Curitiba: Etcetera/Governo do Paraná/Secretaria de Estado da Cultura, 1990. s.p. (poesia com fotos de Jack Pires)

(12) Em nossa análise, tomaremos como base de referência aos poemas, sempre, o primeiro verso; mesmo quando apresentarem título, por questão de uniformidade.

(13) O uso do termo fotografia não tem como referente a imagem de Jack Pires, mas a criada pelo poema.

(14) Em caso extremo, poderíamos pensar até mesmo nos desempregados, os que não estão ocupados na lógica prioritária de reprodução do capital, tendo como referência a expressão tão comum para a despensa dos trabalhadores: "vá para o olho da rua".

(15) LEMINSKI, Paulo. Polonaises. Curitiba: Edição do Autor, 1980b. s.p.

(16) Este poema, quando republicado em Caprichos e relaxos, teve o seu título posto em negrito, tal qual aparece, novamente, em Melhores poemas de Paulo Leminski, na seleção de Fred Góes e Álvaro Marins (2001a:42).

(17) Petrogrado é a forma russa de São Petersburgo, cidade, também, conhecida por Leningrado. (AULETE, 1970:2798)

(18) LEMINSKI, Paulo. Não fosse isso e era menos; não fosse tanto e era quase. Curitiba: ZAP, 1980a. s.p.

(19) LEMINSKI, Paulo. Caprichos e relaxos. São Paulo: Círculo do Livro, 1988. 154p. Este livro reúne poemas já publicados pelo autor - como Polonaises e Não fosse isso e era menos; não fosse tanto e era quase; bem como os da revista Invenção, coordenada por Décio Pignatari, mas também outros, reunidos, também, tal qual os anteriores, como livros dentro do livro: Caprichos e relaxos (saques, piques, toques \& baques), Ideolágrimas, Sol-te e Contos 
semióticos. Caprichos e relaxos é composto, então, por sete partes que são como que livros dentro do livro. Os poemas que já apareceram anteriormente, em Polonaises e Não fosse isso e era menos; não fosse tanto e era quase, tomaremos a liberdade de apenas citá-los, aqui, por seu primeiro verso.

(20) LEMINSKI, Paulo. Distraídos venceremos. 5.ed. São Paulo: Brasiliense, 2002a. 133p.

(21) LEMINSKI, Paulo. La vie en close. 2. reimp. da 5.ed. São Paulo: Brasiliense, 2002b. 181p.

(22) LEMINSKI, Paulo. O ex-estranho. Organização e seleção de Alice Ruiz S. e Áurea Leminski. Curitiba: Iluminuras, 1996. 76p.

\section{Referências}

AULETE, Caldas. Dicionário Contemporâneo da Língua Portuguesa. 2.ed. Rio de Janeiro: Delta, 1970. v.IV.

BAPTISTA, Josely Vianna. Sensu. In: LEMINSKI, Paulo. Winterverno. 1.ed. Curitiba: Iluminuras, $2001 \mathrm{~b}$. s.p. (poesia com desenhos de João Suplicy).

CANDIDO, Antonio. O estudo analítico do poema. São Paulo: FFLCH/USP, 1993. [1.ed. 1967, com base no curso de Teoria Literária de 1963]

GÓES, Fred; MARINS, Álvaro. Labirinto sem limites. In: LEMINSKI, Paulo. Melhores poemas de Paulo Leminski. 1.ed. Seleção Fred Góes e Álvaro Marins. São Paulo: Global, 1996. p.7-25.

HOLLANDA, Heloisa Buarque de. Impressões de viagem; CPC, vanguarda e desbunde: 1960/70. Rio de Janeiro: Rocco, 1992.

LEMINSKI, Paulo. Caprichos e relaxos. São Paulo: Círculo do Livro, 1988. 154p. [1.ed. 1983]

LEMINSKI, Paulo. Diálogo (Entrevista realizada por Almir Feijó, revista Quem, 1978, Curitiba). In: LEMINSKI, Paulo. Paulo Leminski. 2.ed. Seleção e organização de Paulo Leminski. Curitiba: UFPR, 1994. p.9-32. (Série paranaenses; n.2). [1.ed. 1988]

LEMINSKI, Paulo. Distraídos venceremos. 5.ed. São Paulo: Brasiliense, 2002a. 133p. [1.ed. 1987]

LEMINSKI, Paulo. La vie en close. 2. reimp. da 5.ed. São Paulo: Brasiliense, 2002b. 181p. [1.ed. 1991]

LEMINSKI, Paulo. Melhores poemas de Paulo Leminski. 5.ed. Seleção Fred Góes e Álvaro Marins. São Paulo: Global, 2001a. [1.ed. 1996]

LEMINSKI, Paulo. Não fosse isso e era menos; não fosse tanto e era quase. 1.ed. Curitiba: ZAP, 1980a. s.p.

LEMINSKI, Paulo. O ex-estranho. 1.ed. Organização e seleção de Alice Ruiz S. e Áurea Leminski. Curitiba: Iluminuras, 1996. 76p.

LEMINSKI, Paulo. Poesia: a paixão da linguagem. In: NOVAES, Adauto (coord.). Os sentidos da paixão. 9.reimpr. São Paulo: Companhia Das Letras/FUNARTE, 1995. p.283-306. [1.ed. 1987]

LEMINSKI, Paulo. Polonaises. 1.ed. Curitiba: Edição do Autor, 1980b. s.p.

LEMINSKI, Paulo. Quarenta clics em Curitiba. 2.ed. Curitiba: Etcetera/Governo do Paraná/Secretaria de Estado da Cultura, 1990. s.p. (poesia com fotos de Jack Pires). [1.ed. 1976]

LEMINSKI, Paulo. Um escritor na Biblioteca. 1.ed. Curitiba: Biblioteca Pública do Paraná/Secretaria de Estado da Cultura e do Esporte, 1985.

LEMINSKI, Paulo. Winterverno. 1.ed. Curitiba: Iluminuras, 2001b. s.p. (poesia com desenhos de João Suplicy). 
LEMINSKI, Paulo; BONVICINO, Régis. Envie meu dicionário; cartas e alguma crítica. 2.ed. São Paulo: 34, 1999. 270p. [1.ed. 1992]

MACIEL, Maria Esther. Prefácio: A escrita das margens. In: REBUZZI, Solange. Leminski, guerreiro da linguagem; uma leitura das cartas-poemas de Paulo Leminski. Rio de Janeiro: 7Letras, 2003. p.11-4.

NOVAES, Sandra. O reverso do verso; Paulo Leminski Filho: a biografia de uma obra. 2003. 262p. Tese (Doutorado em História: História, Cultura e Sociedade) - Departamento de História do Setor de Ciências Humanas, Letras e Artes, Universidade Federal do Paraná, Curitiba, 2003.

PERRONE-MOISÉS, Leyla. Em voz alta. In: LEMINSKI, Paulo. Paulo Leminski. 2.ed. Seleção e organização de Paulo Leminski. Curitiba: UFPR, 1994. p.51-8. (Série paranaenses; n.2). [Texto publicado, em O Estado de São Paulo, em 1983]

REBUZZI, Solange. Leminski, guerreiro da linguagem; uma leitura das cartas-poemas de Paulo Leminski. Rio de Janeiro: 7Letras, 2003. 94p.

SUPLICY, João. Winterverno; ver-nos. In: LEMINSKI, Paulo. Winterverno. 1.ed. Curitiba: Iluminuras, 2001b. s.p. (poesia com desenhos de João Suplicy).

SUSSEKIND, Flora. Literatura e Vida literária; Polêmicas, diários \& retratos. Rio de Janeiro: Jorge Zahar, 1985.

VAZ, Toninho. Paulo Leminski; O bandido que sabia latim. 1.ed. Rio de Janeiro/São Paulo: Record, 2001. 377p.

VELOSO, Caetano. Reconvexo. Intérprete: Maria Bethânia. In: BETHÂNIA, Maria. Memória da Pele. [S.1.]: PolyGram, 1989. LP. Faixa 1.

Recebido em maio de 2005

Aceito em agosto de 2005 